\title{
Removal of high concentrations of formaldehyde in industrial exhaust by catalytic oxidation
}

\author{
Richu Wei a,b, Honglin Chen ${ }^{\mathrm{b}}$, Xiaoming Zhang ${ }^{\mathrm{b}, *}$, Jishuan Suo ${ }^{\mathrm{b}}$ \\ a University of Chinese Academy of Sciences, Beijing 100049, China \\ ${ }^{\mathrm{b}}$ Chengdu Institute of Organic Chemistry, Chinese Academy of Sciences, Chengdu 610041, Sichuan, China
}

\section{A R T I C L E I N F O}

\section{Article history:}

Received 24 May 2013

Accepted 16 August 2013

Published 20 October 2013

Keywords:

Platinum-ceria/activated carbon catalyst

Formaldehyde waste gas

Glyphosphate production

Formaldehyde removal

\begin{abstract}
A B S T R A C T
A Pt- $-\mathrm{CeO}_{2} / \mathrm{AC}$ catalyst was developed for the removal of high concentrations of formaldehyde (HCHO) in industrial exhaust under mild conditions. The HCHO removal was integrated into a $\mathrm{N}$-(phosphonomethyl)glycine production process to remove in situ the high concentrations of HCHO in its exhaust stream. The HCHO produced and emitted $\left(100-300 \mathrm{mg} / \mathrm{m}^{3}\right)$ in $N$-(phosphonomethyl)glycine synthesis was completely removed by passage through the catalyst bed. The effects of temperature, space velocity, and $\mathrm{HCHO}$ content on removal efficiency were systematically studied. Almost all the HCHO was oxidized at gas hourly space velocities (GHSV) below $20000 \mathrm{~h}^{-1}$, and the $\mathrm{HCHO}$ content was decreased to below $0.1 \mathrm{mg} / \mathrm{m}^{3}$, that is, the $\mathrm{HCHO}$ conversion rate was $99.10 \%-100 \%$. When the GHSV was in the range of $30000-50000 \mathrm{~h}^{-1}$ and the catalyst bed temperature was $12{ }^{\circ} \mathrm{C}$, the $\mathrm{HCHO}$ content in the treated gas was still less than $1.5 \mathrm{mg} / \mathrm{m}^{3}$, and the $\mathrm{HCHO}$ conversion rate was $97.56 \%-99.99 \%$. The $1 \% \mathrm{Pt}-4 \% \mathrm{CeO}_{2} / \mathrm{AC}$ catalyst is now in the pilot phase of its use in treating glyphosphate production exhaust gas containing high concentrations of $\mathrm{HCHO}$, and good initial progress has been made. The concentrations of HCHO in the treated industrial exhaust were less than $10 \mathrm{mg} / \mathrm{m}^{3}$, which effectively has no $\mathrm{HCHO}$ health hazard, and there are good prospects for industrialization.
\end{abstract}

(C) 2013, Dalian Institute of Chemical Physics, Chinese Academy of Sciences. Published by Elsevier B.V. All rights reserved.

\section{Introduction}

Formaldehyde is an important chemical widely used in many industries to manufacture building materials and household products. It is also a byproduct of combustion and chemical processes. The emission of formaldehyde can cause serious damage to the environment and humans. It is a known carcinogen. Many studies have been carried out on the abatement and removal of formaldehyde from the atmosphere, and a number of effective methods have been developed. These include catalytic oxidation [1-20], adsorption purification [21-25], plasma purification [26], and HCHO capture [27-30]. Most of these studies focused on the removal of formaldehyde from indoor environments, in which the concentration of $\mathrm{HCHO}$ is several $\mathrm{mg} / \mathrm{kg}$. In addition to emissions from building projects and decorative materials, waste exhaust gases from industrial processes, such as those used to produce chemicals, electronics, medical products, and pesticides are sources of high concentrations of formaldehyde. In these cases, several hundred or even several thousand $\mathrm{mg} / \mathrm{kg}$ of formaldehyde are present in the exhaust gas stream. The recovery cost is very high, and its direct emission into the atmosphere can cause serious health problems. The methods described above, which were developed for indoor formaldehyde removal, are not suitable for the treatment of industrial waste gases because the concentrations of formaldehyde are too high and the corresponding treatment costs are unacceptable.

Pt catalysts have been widely researched for the removal of

*Corresponding author. Tel: +86-28-85226215; Fax: +86-28-85223978; E-mail: xm.zhang@cioc.ac.cn 
formaldehyde at room temperature [31-36]. A $1 \mathrm{wt} \% \mathrm{Pt} / \mathrm{TiO}_{2}$ catalyst was shown to be effective for $\mathrm{HCHO}$ oxidation at room temperature, and $100 \%$ conversion of $\mathrm{HCHO}(100 \mathrm{mg} / \mathrm{kg})$ was achieved at a gas hourly space velocity (GHSV) of $50000 \mathrm{~h}^{-1}$ $[37,38]$. Pt $/ \mathrm{CeO}_{2}$ catalyst with $3 \mathrm{wt} \% \mathrm{Pt}$ can catalyze the oxidation of $\mathrm{HCHO}(500 \mathrm{mg} / \mathrm{kg})$ to $\mathrm{CO}_{2}$ and $\mathrm{H}_{2} \mathrm{O}$ at a GHSV of 60000 $\mathrm{h}^{-1}$ at $100{ }^{\circ} \mathrm{C}$ [39]. A Na-Pt/ $\mathrm{TiO}_{2}$ catalyst was effective for the conversion of $\mathrm{HCHO}(600 \mathrm{mg} / \mathrm{kg})$ to $\mathrm{CO}_{2}$ and $\mathrm{H}_{2} \mathrm{O}$ at a GHSV of $120000 \mathrm{~h}^{-1}$ [40]. All these catalysts were Pt catalysts supported on a metal oxide, and the catalyst prices were high due to the high content of Pt. Recently, an efficient Pt-CeO 2 /AC (AC: activated carbon) catalyst was developed for in situ removal of formaldehyde for the treatment of glyphosphate waste solution using a combined vacuum-distillation and catalytic oxidation process. The addition of Ce into the Pt catalyst increased the catalytic activity and decreased the catalyst price [41]. The high concentration of formaldehyde vapor formed during the distillation was directly oxidized to $\mathrm{CO}_{2}$ and $\mathrm{H}_{2} \mathrm{O}$ under mild conditions in the presence of air and the catalyst. In the present study, the Pt- $\mathrm{CeO}_{2} / \mathrm{AC}$ catalyst was used for the catalytic oxidation of waste gases containing high concentrations of formaldehyde produced during glyphosphate production. In this process, formaldehyde was produced during the air oxidation of $\mathrm{N}$-(phosphonomethyl)iminodiacetic acid to $\mathrm{N}$-(phosphonomethyl)glycine (i.e. glyphosphate), an important herbicide. By installing a Pt- $\mathrm{CeO}_{2} / \mathrm{AC}$ catalyst column in the outlet stream of the glyphosphate synthesis, the high concentration of formaldehyde in the exhaust gas stream was directly oxidized to $\mathrm{CO}_{2}$ and $\mathrm{H}_{2} \mathrm{O}$, and the concentration of formaldehyde was decreased from several hundred $\mathrm{mg} / \mathrm{m}^{3}$ to below $1 \mathrm{mg} / \mathrm{m}^{3}$.

\section{Experimental}

\subsection{Catalyst preparation}

First, $2.0 \mathrm{~g}$ of $\mathrm{Ce}\left(\mathrm{NO}_{3}\right)_{3} \cdot 6 \mathrm{H}_{2} \mathrm{O}$ was dissolved in $200.0 \mathrm{ml}$ of deionized water with stirring. Then $20.0 \mathrm{~g}$ of AC (20-60 mesh) was added. After stirring for $18 \mathrm{~h}$, the sample was filtered, washed with deionized water, dried in vacuum at $125{ }^{\circ} \mathrm{C}$ for 5 $\mathrm{h}$, and calcined at $350{ }^{\circ} \mathrm{C}$ in nitrogen atmosphere for $2 \mathrm{~h}$. The sample produced was designated $\mathrm{CeO}_{2} / \mathrm{AC}$.

For depositing Pt on the catalyst, $20.0 \mathrm{~g}$ of $\mathrm{CeO}_{2} / \mathrm{AC}$ sample was dispersed in $200.0 \mathrm{ml}$ of deionized water, and $26.6 \mathrm{ml}$ of $\mathrm{H}_{2} \mathrm{PtCl}_{6}$ solution $(3.75 \mathrm{mg} / \mathrm{ml})$ was added dropwise under stirring. Then the $\mathrm{pH}$ of the solution was adjusted to 10.5 with aqueous $\mathrm{NaOH}$ solution. After stirring continuously overnight, the sample was filtered, washed with deionized water, and dried in vacuum at $125^{\circ} \mathrm{C}$ for $8 \mathrm{~h}$. The Pt-CeO $/ \mathrm{AC}$ catalyst was obtained by reducing the sample at $400{ }^{\circ} \mathrm{C}$ with $\mathrm{H}_{2}\left(20 \%\right.$ in $\left.\mathrm{N}_{2}\right)$ for $5 \mathrm{~h}$.

\subsection{Catalyst characterization}

The metal content of the catalysts was determined using an X Series" II device (Perkin Elmer Company, USA). $\mathrm{N}_{2}$ adsorption isotherms were obtained with an SSA-4200 specific surface area and pore size analyzer (Builder Company, China). The fresh catalysts were further characterized using X-ray photoelectron spectroscopy (XPS, XSAM 800 photoelectron spectroscope, Kratos Company, Britain). The average particle size was obtained using a high resolution transmission electron microscope (HRTEM) and a Tecnai G² F20 S-Twin device (FEI Company, Germany) with $200 \mathrm{kV}$ accelerating voltage. The phase structure of the catalysts was characterized with an X'pert Pro MPD XRD (PANalytical Company, Holland) using $\mathrm{Cu} K_{\alpha}(\lambda=$ $0.15406 \mathrm{~nm}$ ) radiation.

\subsection{Activity test}

The exhaust tail gas containing high concentrations of $\mathrm{HCHO}$ was produced during the air oxidation of $\mathrm{N}$-(phosphonomethyl)iminodiacetic acid to $N$-(phosphonomethyl)glycine in an autoclave. This gas was treated with the $\mathrm{Pt}-\mathrm{CeO}_{2} / \mathrm{AC}$ catalyst. $\mathrm{HCHO}$ in untreated gas and treated gas that had passed through a packed bed of the $\mathrm{Pt}-\mathrm{CeO}_{2} / \mathrm{AC}$ catalyst was adsorbed using a bubble absorption tube with distilled water. Then the absorbance of the adsorbed water was measured using an ultraviolet visible spectrophotometer (UV-2000, USA), and the concentration of HCHO was calculated [42].

\section{Results and discussion}

\subsection{Catalytic performance of $0.5 \% \mathrm{Pt}-4 \% \mathrm{CeO}_{2} / \mathrm{AC}$ catalyst}

The reaction of the AC-catalyzed air oxidation of $N$-(phosphonomethyl)iminodiacetic acid (PMIDA) to $\mathrm{N}$-(phosphonomethyl)glycine (PMG) is as follow:

$$
\begin{gathered}
(\mathrm{HO})_{2} \mathrm{P}(\mathrm{O}) \mathrm{CH}_{2} \mathrm{~N}\left(\mathrm{CH}_{2} \mathrm{CO}_{2} \mathrm{H}\right)_{2}+1 / 2 \mathrm{O}_{2} \rightarrow \\
(\mathrm{HO})_{2} \mathrm{P}(\mathrm{O}) \mathrm{CH}_{2} \mathrm{NHCH}_{2} \mathrm{CO}_{2} \mathrm{H}+\mathrm{CO}_{2}+\mathrm{HCHO}
\end{gathered}
$$

Formaldehyde was gradually produced in the reaction. Most of the HCHO was dissolved in the liquid phase, and the final concentration of $\mathrm{HCHO}$ in the reaction stream was about $2 \%-3 \%$ when the initial concentration of $N$-(phosphonomethyl)iminodiacetic acid was $25 \%$. Due to its high volatility, HCHO was inevitably emitted into the exhaust stream of the oxidation autoclave. In order to simulate the experimental conditions of PMG production and evaluate the catalytic performance of the $0.5 \% \mathrm{Pt}-4 \% \mathrm{CeO}_{2} / \mathrm{AC}$ catalyst, $300 \mathrm{~g}$ of $2.5 \% \mathrm{HCHO}$ solution was placed in the autoclave, air was fed into the autoclave at $0.6 \mathrm{MPa}$ and $65^{\circ} \mathrm{C}$, and the exhaust stream was passed through the $0.5 \% \mathrm{Pt}-4 \% \mathrm{CeO}_{2} / \mathrm{AC}$ catalyst bed. The concentrations of HCHO before and after passage through the catalyst bed were analyzed quantitatively. The results are listed in Table 1 . The concentration of HCHO in the exhaust of the autoclave increased almost linearly as the air flow rate increased. Almost all the HCHO was oxidized when the GHSV was below $20000 \mathrm{~h}^{-1}$, and the HCHO content in the treated exhaust stream was below $0.1 \mathrm{mg} / \mathrm{m}^{3}$, which was far lower than the emission standard for an industrial exhaust. Further increases in the rate of air flow led to an increase in the HCHO concentration in the treated exhaust stream. The catalyst activity was about 325 $\mathrm{nmol} /(\mathrm{g} \cdot \mathrm{h})$ for the complete removal of HCHO.

\subsection{Catalytic performance of $1 \% \mathrm{Pt}-4 \% \mathrm{CeO}_{2} / \mathrm{AC}$ catalyst}


Table 1

Treatment of air contaminated with $\mathrm{HCHO}$ at $25^{\circ} \mathrm{C}$.

\begin{tabular}{|c|c|c|c|c|c|}
\hline \multirow{2}{*}{$\begin{array}{l}\text { Air flow rate } \\
(\mathrm{ml} / \mathrm{min})\end{array}$} & \multicolumn{2}{|c|}{ HCHO content $\left(\mathrm{mg} / \mathrm{m}^{3}\right)$} & \multirow{2}{*}{ GHSV $\left(h^{-1}\right)$} & \multirow{2}{*}{ Conversion (\%) } & \multirow{2}{*}{$\begin{array}{c}\text { Catalytic activity } \\
\text { (nmol/(g.h)) }\end{array}$} \\
\hline & Before treatment & After treatment & & & \\
\hline 400 & 15.6 & - & 4000 & 100.00 & 4.5 \\
\hline 600 & 58.3 & - & 6000 & 100.00 & 25.0 \\
\hline 800 & 75.0 & - & 8000 & 100.00 & 42.9 \\
\hline 1000 & 100.0 & 0.02 & 10000 & 99.98 & 71.4 \\
\hline 1500 & 140.0 & 0.03 & 15000 & 99.98 & 150.0 \\
\hline 2000 & 227.5 & 0.10 & 20000 & 99.96 & 324.9 \\
\hline 3000 & 300.6 & 10.5 & 30000 & 96.51 & 621.6 \\
\hline
\end{tabular}

Experimental conditions: $0.5 \% \mathrm{Pt}-4 \% \mathrm{CeO}_{2} / \mathrm{AC}$ (20-60 mesh) catalyst $6 \mathrm{ml}$ (2.8 g). By changing the air flow rate, the $\mathrm{GHSV}_{\text {was }} 4000-30000 \mathrm{~h}^{-1}$.

Based on these experimental results, the catalytic oxidation of $\mathrm{HCHO}$ was integrated into the process of $\mathrm{N}$-(phosphonomethyl)glycine synthesis. In a typical procedure, $80.0 \mathrm{~g}$ of PMIDA, $12.7 \mathrm{~g}$ of activated carbon, and $240 \mathrm{~g}$ of distilled water were added to a $500 \mathrm{ml}$ autoclave. The autoclave was sealed, the temperature was increased to $65{ }^{\circ} \mathrm{C}$, and the rotational speed was increased to $800 \mathrm{r} / \mathrm{min}$. Then $400 \mathrm{ml} / \mathrm{min}$ of air at $0.6 \mathrm{MPa}$ pressure was fed into the autoclave and the reaction was initiated. The vent gases of the autoclave were introduced directly into a packed bed of $1 \% \mathrm{Pt}-4 \% \mathrm{CeO}_{2} / \mathrm{AC}$ catalyst. The $\mathrm{HCHO}$ contents at the inlet and outlet of the catalyst bed were analyzed and the HCHO conversion was calculated.

The oxidation of PMIDA to PMG was carried out in a batch manner. The reaction was terminated when the conversion of PMIDA reached about 98\% because prolonging the reaction further can decrease the PMG yield. Under these reaction conditions, the oxidation reaction was complete within $170 \mathrm{~min}$. The HCHO content versus time in the exit stream of the autoclave is shown in Table 2. The HCHO concentration increased gradually and reached a maximum at the end of the reaction. The exit stream of the oxidation autoclave was introduced directly into the $1 \% \mathrm{Pt}-4 \% \mathrm{CeO}_{2} / \mathrm{AC}$ catalyst bed. The $\mathrm{HCHO}$ conversion versus time in the outlet stream of the catalyst bed during the reaction period at different temperatures is shown in Fig. 1. The HCHO in the gas stream from the oxidation of PMIDA was completely oxidized as it passed through the catalyst bed, and the HCHO concentrations in the treated waste gases were below $0.1 \mathrm{mg} / \mathrm{m}^{3}$ throughout the reaction period. A lower temperature in the catalyst bed gave a higher performance with respect to removing $\mathrm{HCHO}$, but the difference was small.

The amount of catalyst was changed in order to assess the dependence of HCHO removal efficiency on the gas hourly space velocity. Figure 2 shows the HCHO conversions at different GHSVs throughout the PMIDA oxidation period. During the initial stage of the oxidation reaction, the HCHO concentrations in the treated stream were very low when the GHSV was varied

Table 2

$\mathrm{HCHO}$ content in the tail gas during PMG production.

\begin{tabular}{lc}
\hline Reaction time $(\mathrm{min})$ & HCHO content $\left(\mathrm{mg} / \mathrm{m}^{3}\right)$ \\
\hline 30 & 7.80 \\
65 & 25.80 \\
100 & 53.79 \\
135 & 109.13 \\
170 & 174.61 \\
\hline
\end{tabular}

from 20000 to $50000 \mathrm{~h}^{-1}$. Differences appeared gradually as the reaction continued. At the end of the oxidation reaction, the $\mathrm{HCHO}$ content in the treated waste gas was about $1.5 \mathrm{mg} / \mathrm{m}^{3}$ with $98 \%$ of conversion when the GHSV was $50000 \mathrm{~h}^{-1}$, which was about 20 times higher than that observed for $20000 \mathrm{~h}^{-1}$ GHSV. This indicates that $30000 \mathrm{~h}^{-1}$ of GHSV was the optimum GHSV value for the present PMIDA oxidation conditions, and the HCHO content in the treated waste gas was reduced to below $0.2 \mathrm{mg} / \mathrm{m}^{3}$. In this case, the catalyst activity was 517 $\mathrm{nmol} /(\mathrm{g} \cdot \mathrm{h})$, which was consistent with the results in Table 1.

Figure 3 shows the reusability of the catalyst with respect to its ability to remove HCHO from the exhaust stream. The same

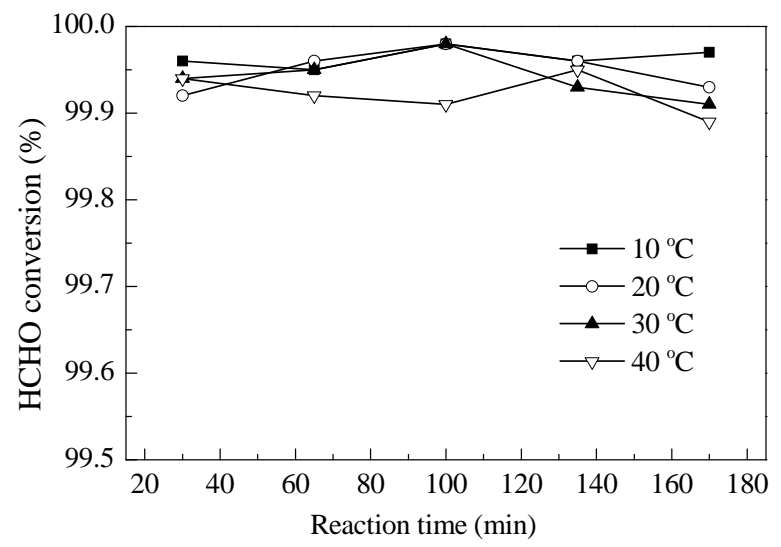

Fig. 1. HCHO conversion through the catalyst bed. Reaction conditions: catalyst $1.20 \mathrm{ml}(0.41 \mathrm{~g})$, GHSV $20000 \mathrm{~h}^{-1}$.

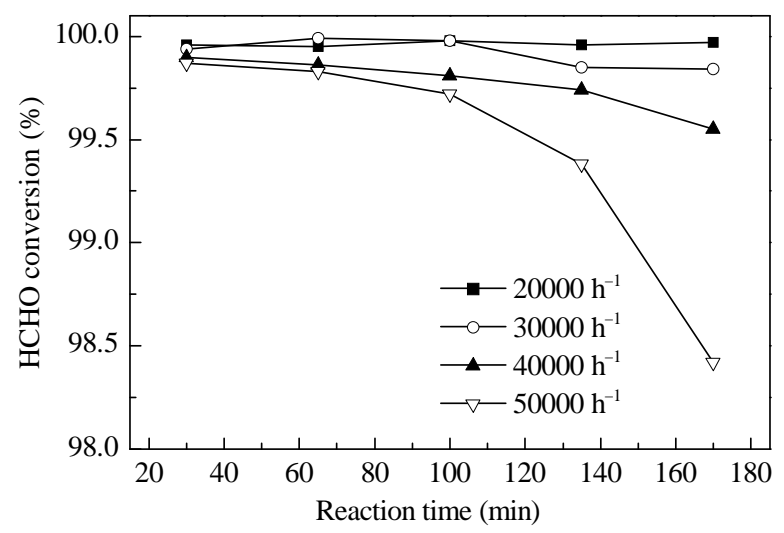

Fig. 2. HCHO conversion at different GHSV at the same temperature. Reaction conditions: tail gas speed $400 \mathrm{ml} / \mathrm{min}$, catalyst $1.2 \mathrm{ml}$, temperature $12{ }^{\circ} \mathrm{C}$. The catalyst volume was decreased over time to increase the gas hourly space velocity. 


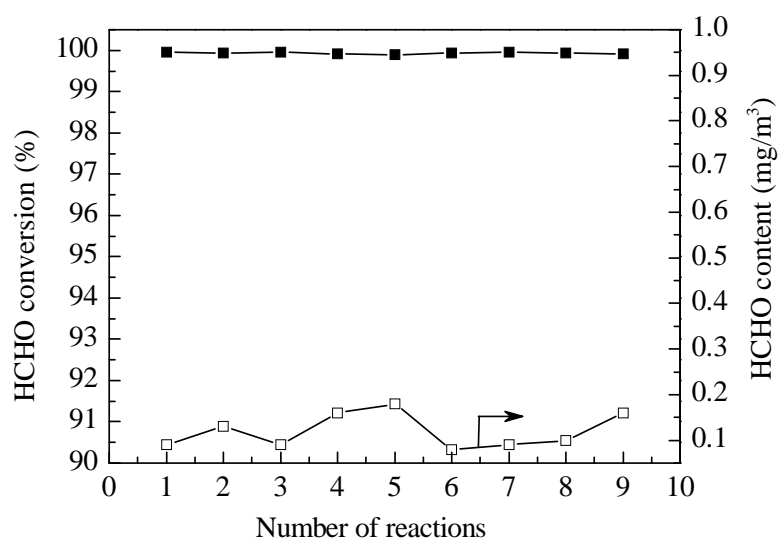

Fig. 3. $\mathrm{HCHO}$ conversion at $10{ }^{\circ} \mathrm{C}$ during catalyst recycle. Reaction conditions: catalyst $0.80 \mathrm{ml}(0.28 \mathrm{~g})$, GHSV $30000 \mathrm{~h}^{-1}$.

catalyst was used repeatedly in different cycles of PMIDA oxidation. The HCHO conversion remained higher than $99.9 \%$ in all runs, and the $\mathrm{HCHO}$ content of the treated gases remained below $0.2 \mathrm{mg} / \mathrm{m}^{3}$, suggesting that the $1 \% \mathrm{Pt}-4 \% \mathrm{CeO}_{2} / \mathrm{AC}$ catalyst was quite stable and can remove high concentrations of HCHO from the industrial exhaust stream.

Based on the results, $40 \mathrm{~kg}$ of $1 \% \mathrm{Pt}-4 \% \mathrm{CeO}_{2} / \mathrm{AC}$ catalyst was prepared and used to treat the exhaust stream of a PMG production plant. Waste gases containing $100-300 \mathrm{mg} / \mathrm{m}^{3}$ HCHO were fed into the catalyst bed at a flow rate of 3000 $\mathrm{m}^{3} / \mathrm{h}$. The HCHO content in the treated stream was below 10 $\mathrm{mg} / \mathrm{m}^{3}$, which satisfied the emission standard for an industrial exhaust.

\subsection{Characteristics of the catalysts}

The metal content and pore structure of the $\mathrm{Pt}-\mathrm{CeO}_{2} / \mathrm{AC}$ catalysts were characterized. The results are shown in Table 3. The Pt and Ce contents in the catalysts were lower than the amounts of these substances added during catalyst preparation. The physical characteristics of the two catalysts were almost the same.

The XRD patterns of the $\mathrm{CeO}_{2} / \mathrm{AC}, \mathrm{Pt} / \mathrm{AC}$, and $\mathrm{Pt}-\mathrm{CeO}_{2} / \mathrm{AC}$ catalysts are shown in Fig. 4. The characteristic peaks of Pt $(2 \theta$ $=39.8^{\circ}$ and $67.5^{\circ}$ ) were observed in the XRD patterns of Pt/AC

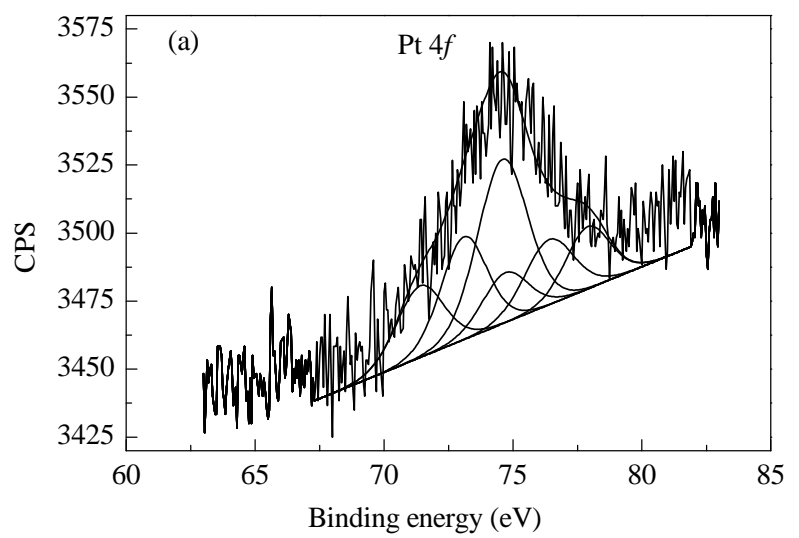

Table 3

Metal contents and pore structure of the $\mathrm{Pt}-\mathrm{CeO}_{2} / \mathrm{AC}$ (40-80 mesh) catalysts.

\begin{tabular}{|c|c|c|c|c|c|}
\hline \multirow{2}{*}{ Catalyst } & \multicolumn{2}{|c|}{ Metal contents (wt $\%$ ) } & \multirow{2}{*}{$\begin{array}{c}A_{\mathrm{BET}} \\
\left(\mathrm{m}^{2} / \mathrm{g}\right)\end{array}$} & \multirow{2}{*}{$\begin{array}{c}V \\
\left(\mathrm{~cm}^{3} / \mathrm{g}\right)\end{array}$} & \multirow{2}{*}{$\begin{array}{c}D \\
(\mathrm{~nm})\end{array}$} \\
\hline & $\mathrm{Pt}$ & $\mathrm{Ce}$ & & & \\
\hline $0.5 \% \mathrm{Pt}-4 \% \mathrm{CeO}_{2} / \mathrm{AC}$ & 0.35 & 1.53 & 810 & 0.42 & 1.04 \\
\hline $1 \% \mathrm{Pt}-4 \% \mathrm{CeO}_{2} / \mathrm{AC}$ & 0.80 & 2.06 & 817 & 0.43 & 1.04 \\
\hline
\end{tabular}

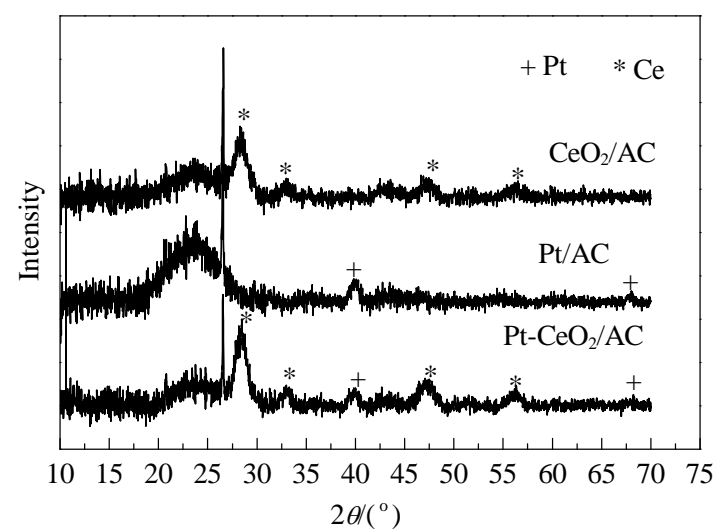

Fig. 4. $\mathrm{XRD}$ patterns of the $\mathrm{CeO}_{2} / \mathrm{AC}, \mathrm{Pt} / \mathrm{AC}$, and $1 \% \mathrm{Pt}-4 \% \mathrm{CeO}_{2} / \mathrm{AC}$ catalysts.

and Pt- $\mathrm{CeO}_{2} / \mathrm{AC}$, indicating that Pt was highly dispersed on the catalyst surface.

XPS is a valuable tool for characterizing the electronic properties of a material and its chemical state. Figure 5 shows the XPS spectra of the Pt-CeO $/$ AC catalyst for Pt and $\mathrm{Ce}$. The peaks at 71.4 and $74.65 \mathrm{eV}$ were attributed to metallic Pt, and the peaks at 73.1 and $76.4 \mathrm{eV}$ were attributed to the presence of $\mathrm{PtO}$ or $\mathrm{Pt}(\mathrm{OH})_{2}$, and the peaks at 74.71 and $77.9 \mathrm{eV}$ were attributed to the presence of $\mathrm{PtO}_{2}[43,44]$ (Fig. 5(a)). The peaks at 887.04 and $905.25 \mathrm{eV}$ were typical of $\mathrm{Ce}^{3+}$, and the main features of $\mathrm{Ce}^{4+}$ appeared at 883.07, 890.14, 898.88, 901.65, 908.0, and $917.63 \mathrm{eV}[45,46]$ (Fig. 5(b)). The relative composition of $\mathrm{Ce}^{3+}$ was $14.90 \%$ and that of $\mathrm{Ce}^{4+}$ was $85.10 \%$.

\section{Conclusions}

A Pt- $\mathrm{CeO}_{2} / \mathrm{AC}$ catalyst was effective for the removal of high concentrations of $\mathrm{HCHO}$ from an industrial exhaust under mild

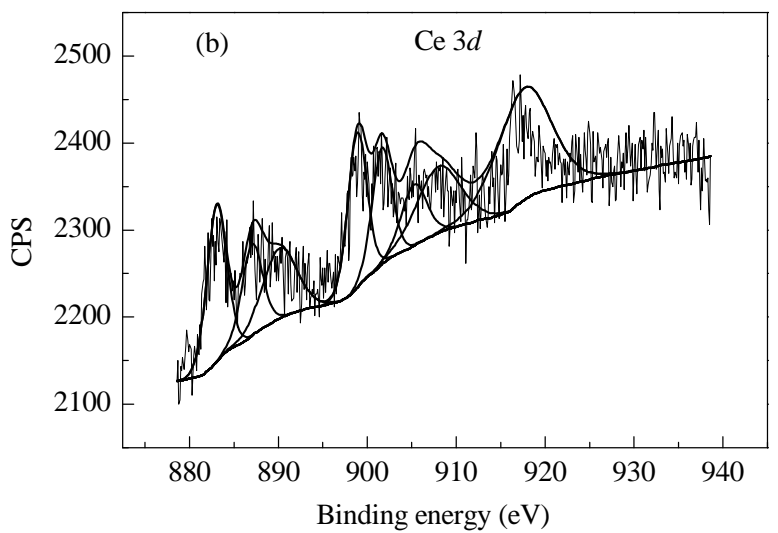

Fig. 5. XPS spectra of the $1 \% \mathrm{Pt}-4 \% \mathrm{CeO}_{2} / \mathrm{AC}$ catalyst. (a) Pt $4 f$; (b) Ce $3 d$. 


\title{
Graphical Abstract
}

\author{
Chin. J. Catal., 2013, 34: 1945-1950 doi: 10.1016/S1872-2067(12)60696-2
}

Removal of high concentrations of formaldehyde in industrial exhaust by catalytic oxidation

Richu Wei, Honglin Chen, Xiaoming Zhang*, Jishuan Suo

University of Chinese Academy of Sciences;

Chengdu Institute of Organic Chemistry, Chinese Academy of Sciences

The Pt-CeO $/$ AC catalyst was used to remove the high concentration formaldehyde in industrial exhaust, and the HCHO content in the treated stream dropped below $0.1 \mathrm{mg} / \mathrm{m}^{3}$ at GHSV of $20000 \mathrm{~h}^{-1}$.

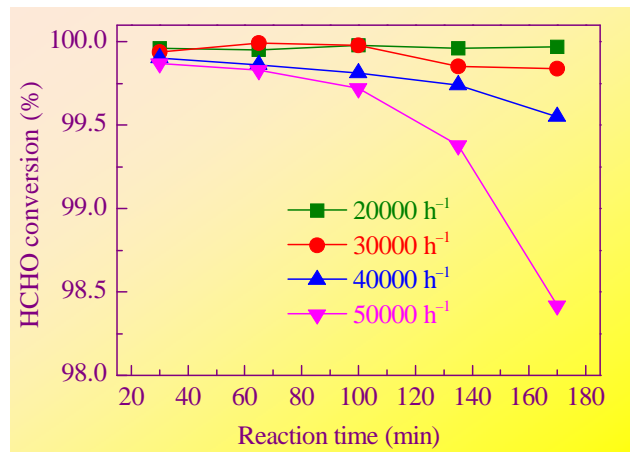

conditions. By connecting a packed catalyst bed to the outlet of the oxidation autoclave of a PMG production system, the HCHO in the exhaust stream was completely oxidized as it passed through the catalyst bed. The HCHO content of the treated gas stream was below $1 \mathrm{mg} / \mathrm{m}^{3}$. The catalyst and method can be used in various industrial processes that have high concentrations of formaldehyde.

\section{References}

[1] Spivey J J. Ind Eng Chem Res, 1987, 26: 2165

[2] Scirè S, Minicò S, Crisafulli C, Satriano C, Pistone A. Appl Catal B, 2003, 40: 43

[3] Scirè S, Minicò S, Crisafulli C, Galvagno S. Catal Commun, 2001, 2: 229

[4] Sawyer J E, Abraham M A. Ind Eng Chem Res, 1994, 33: 2084

[5] Papaefthimiou P, Ioannides T, Verykios X E. Catal Today, 1999, 54: 81

[6] Wang W, Zhang H B, Lin G D, Xiong Z T. Appl Catal B, 2000, 24: 219

[7] Cordi E M, Falconer J L. Appl Catal A, 1997, 151: 179

[8] Saleh J M, Hussain S M. J Chem Soc, Faraday Trans, 1986, 82: 2221

[9] Imamura S, Uchihori D, Utani K, Ito T. Catal Lett, 1994, 24: 377

[10] Álvarez-Galván M C, de la Peña O’Shen V A, Fierro J L G, Arias P L. Catal Commun, 2003, 4: 223

[11] Cordi E M, O’Neill P J, Falconer J L. Appl Catal B, 1997, 14: 23

[12] Larsson P O, Andersson A. Appl Catal B, 2000, 24: 175

[13] Mazzocchia C, Kaddouri A. J Mol Catal A, 2003, 204-205: 647

[14] Kim S C.J Hazard Mater, 2002, 91: 285

[15] Sekine Y. Atmos Environ, 2002, 36: 5543

[16] Huang H B, Leung D Y C. ACS Catal, 2011, 1: 348

[17] Shi C, Wang Y, Zhu A M, Chen B B, Au C. Catal Commun, 2012, 28: 18

[18] Liu B C, Liu Y, Li C Y, Hu W T, Jing P, Wang Q Zhang J. Appl Catal B, 2012, 127: 47

[19] Park S J, Bae I, Nam I-S, Cho B K, Jung S M, Lee J-H. Chem Eng J, 2012, 195-196: 392

[20] Wang Y, Zhu A M, Chen B B, Crocker M, Shi C. Catal Commun, 2013, 36: 52

[21] Wachs I E, Madix R J. Surf Sci, 1979, 84: 375

[22] Wachs I E, Madix R J. Appl Surf Sci, 1980, 5: 426

[23] Lu X, Zhang Q E, Lin M C. Phys Chem Chem Phys, 2001, 3: 2156

[24] Zhou J, Mullins D R. Surf Sci, 2006, 600: 1540
[25] Li C, Domen K, Maruya K-I, Onishi T.J Catal, 1990, 125: 445

[26] Li J, Xue H D, Liang W J, Li J, Jin Y K, Li Y L. Beijing Univ Technol (李 坚, 薛红弟, 梁文俊, 李洁, 金毓奎, 李依丽. 北京工业大学学报), 2006, 32: 534

[27] Koizumi M. JP 2002273 145. 2002

[28] Rozynov B V, Coyle W J, Wood W E, Beaverson N J. US 6541560. 2003

[29] Kakkar R, Kapoor P N, Klabunde K J. J Phys Chem B, 2004, 108: 18140

[30] Cowan J, Abu-Daabes M, Banerjee S. Environ Sci Technol, 2005, 39: 5101

[31] Tang X F, Chen J L, Huang X M, Xu Y D, Shen W J. Appl Catal B, 2008, 81: 115

[32] He Y B, Ji H B. Chin J Catal (何运兵, 纪红兵. 催化学报), 2010, 31: 171

[33] An N H, Yu Q S, Liu G, Li S Y, Jia M J, Zhang W X. J Hazard Mater, 2011, 186: 1392

[34] Liu L L, Tian H, He J H, Wang D H, Yang Q W. J Environ Sci, 2012, 24: 1117

[35] Tian H, He J H, Liu L L, Wang D H. Ceram Int, 2013, 39: 315

[36] An N H, Zhang W L, Yuan X L, Pan B, Liu G, Jia M J, Yan W F, Zhang W X. Chem Eng J, 2013, 215-216: 1

[37] Zhang C B, He H, Tanaka K-I. Catal Commun, 2005, 6: 211

[38] Zhang C B, He H, Tanaka K-I. Appl Catal B, 2006, 65: 37

[39] Shi Y Z, Zhang N, Luo M F, Lu J Q.J Chin Soc Rare Earth (石艳芝, 张 娜, 罗孟飞, 鲁继青. 中国稀土学报), 2011, 29: 271

[40] Zhang C B, Liu F D, Zhai Y P, Ariga H, Yi N, Liu Y C, Asakura K, Flytzani-Stephanopoulos M, He H. Angew Chem Int Ed, 2012, 51: 9628

[41] Wei R C, Chen H L, Zhang X M. Ind Catal (魏日出, 陈洪林, 张小明. 工业催化), 2012, 20(10): 68

[42] State Environmental Protection Administration. Water and Wastewater Monitoring Analysis Method. 4th Ed. Beijing: China Environmental Science Press (国家环境保护总局水和废水监测分 析方法编委会. 水和废水监测分析方法. 第4版. 北京: 中国环境 科学出版社), 2002

[43] Wu F, Liu Y H, Wu C. J Wuhan Univ Technol Mater Sci Ed, 2011, 26: 377

[44] Scibioh M A, Kim S K, Cho E A, Lim T H, Hong S A, Ha H Y. Appl Catal B, 2008, 84: 773

[45] Reddy B M, Thrimurthulu G, Katta L, Yamada Y, Park S E. J Phys Chem C, 2009, 113: 15882

[46] Larachi F, Pierre J, Adnot A, Bernis A. Appl Surf Sci, 2002, 195: 236 


\title{
催化氧化处理工业废气中高浓度甲醛
}

\author{
魏日出 ${ }^{\mathrm{a}, \mathrm{b}}$, 陈洪林 ${ }^{\mathrm{b}}$, 张小明 ${ }^{\mathrm{b},{ }^{*}}$, 索继栓 ${ }^{\mathrm{b}}$ \\ a国科学院大学, 北京100049 \\ 中国科学院成都有机化学研究所, 四川成都610041
}

摘要: 制备了用于温和条件下催化氧化去除工业废气中高浓度甲醛(HCHO)的 $1 \% \mathrm{Pt}-4 \% \mathrm{CeO}_{2} / \mathrm{AC}$ 催化剂. 将高浓度甲醛的催化氧 化过程与双甘膦氧化制备草甘膦的反应过程集成在一起, 使草甘膦合成过程中产生和排放出来的甲醛 $\left(100-300 \mathrm{mg} / \mathrm{m}^{3}\right)$ 在通过催 化剂床层时被完全除去. 系统研究了温度、空速和甲醛含量对甲醛去除率的影响. 在气体空速(GHSV)低于 $20000 \mathrm{~h}^{-1}$ 时废气中几 乎所有的甲醛都被氧化, 处理后的废气中的甲醛含量低于 $0.1 \mathrm{mg} / \mathrm{m}^{3}$, 甲醛的转化率为 $99.1 \%-100 \%$. 当GHSV为 $30000-50000 \mathrm{~h}^{-1}$, 催化剂床层温度为 $12{ }^{\circ} \mathrm{C}$ 时, 生产废气通过催化剂床层后的甲醛含量小于 $1.5 \mathrm{mg} / \mathrm{m}^{3}$, 甲醛的转化率为 $97.56 \%-99.99 \%$. $1 \% \mathrm{Pt}-4 \% \mathrm{CeO}_{2} / \mathrm{AC}$ 催化剂的中试试验结果表明, 处理后最终尾气中甲醛含量小于 $10 \mathrm{mg} / \mathrm{m}^{3}$, 有效地防止了甲醛对人们健康的危害, 具有良好的产业化前景.

关键词：铂-二氧化铈/活性炭催化剂; 甲醛废气; 草甘膦生产; 甲醛去除

收稿日期: 2013-05-24. 接受日期: 2013-08-16. 出版日期: 2013-10-20.

*通讯联系人. 电话: (028)85226215; 传真: (028)85223978; 电子信箱: xm.zhang@cioc.ac.cn

本文的英文电子版由Elsevier出版社在ScienceDirect上出版(http://www.sciencedirect.com/science/journal/18722067). 